\title{
PRILAKU BELAJAR DALAM KONSEP \\ PENDIDIKAN ISLAM
}

Nurlila Kamsi

STAI Bumi Silampari Lubuklinggau

kamsi@staibsllg.ac.id

\begin{tabular}{ll}
\hline Abstrak & The view of Islamic education is \\
\hline Article History & something that is incumbent on \\
Received :05-09-2019 & humans, with human education \\
Revised :06-09-2019 & haining knowledge to form a much \\
Accepted:07-09-2019 & gaing \\
\hline Keywords: & better behavior. in this study \\
Learning Behavior, & examines Islamic business \\
The Concept of Islamic education learning behavior in \\
Education & schools is expected to be able to \\
& shape personal piety and social \\
& piety at the same time. Learning \\
& behavior in the concept of Islamic \\
& education with literature research \\
& methods. Assess based on relevant \\
& sources. The results of this study \\
& that learning behavior is a matter \\
& of great concern for teachers to \\
& understand the theory and practice \\
& based on the a-Qur'an. And the \\
& formation of a Muslim personality \\
& and the achievement of learning \\
& objectives.
\end{tabular}

\section{Pendahuluan}

Kegiatan (pembelajaran) pendidikan agama Islam diarahkan untuk meningkatkan keyakinan, pemahaman, penghayatan dan pengamalan ajaran Agama Islam dari peserta didik, yang disamping untuk kesalehan atau kualitas pribadi, juga sekaligus untuk membentuk kesalehan sosial. Usaha pembelajaran Pendidikan Agama Islam di sekolah diharapkan agar mampu membentuk kesalehan pribadi dan sekaligus kesalehan sosial sehingga pendidikan Agama Islam diharapkan jangan sampai menumbuhkan 
sikap toleran dikalangan peserta didik dan masyarakat Indonesia; dan (b) Memperkuat kerukunan hidup beragama serta persatuan dan kesatuan nasional. Walhasil pendidikan agama Islam diharapkan mampu menciptakan ukhuwah Islamiyah dalam arti luas, yaitu ukhuwah fi al-'ubudiyah, ukhuwah fi al- insaniyah, ukhuwah fi alwathaniyah wa al-nasab, dan ukhuwah fi din al-Islam. (http://suhatman-ate.blogspot.com/2009/01/pentingnyapendidikanagama-islam. tanggal 24 Mei 2013:2)

Dalam konteks pendidik Islam "sering disebut dengan murabbi, muallim, mu'addib, mudarris, dan mursyid. Kelima istilah tersebut mempunyai tempat tersendiri menurut peristilahan yang dipakai dalam pendidikan dalam konteks islam. Disamping itu, istilah pendidik kadang kala disebut melalui gelarnya, seperti ustadz dan al-syaikh. Sebagaimana teori barat, pendidik dalam Islam adalah "orang-orang yang bertanggung jawab terhadap perkembangan peserta didiknya dengan upaya mengembangkan seluruh potensi peserta didik, baik potensi afektif (rasa), kognitif (cipta), dan psikomotorik (karsa)". (Ahmad Tafsir, 2005: 74)

Penulis akan menguraikan sedikit tentang pendidikan menurutnya M. Arifin dalam bukunya pendidikan berkembang dari yang sederhana (primitif), yang berlangsung ketika manusia masih berada dalam ruang lingkup kehidupan yang serba sederhana serta konsep tujuan yang amat terbatas pada hal-hal yang bersifat survival (pertahanan hidup terhadap alam sekitar), sampai pada bentuk pendidikan yang sarat pada metode, tujuan, serta model pendidikan yang sesuai dengan masyarakat saat ini. Adapun metode dasar untuk mendidik manusia agar mampu mengembangkan diri dalam kehidupan yang makin luas dan kompleks, terutama dalam memahami, menghayati. Dan mengamalkan misi agama Islam, berpangkal pada kemampuan "membaca", dan "menulis" dengan kalam. Tidak sekedar "membaca" tulisan atau "menuliskan" hasil pengamatan, akan tetapi juga membaca, memahami, dan menjelaskan gejala alamiah yang diciptakan Tuhan dalam alam semesta ini. Sekaligus menganalisis untuk sampai pada kemampuan "membaca".

Pengertian pendidikan menurut para ahli, memberikan uraian dan pandangan tentang masalah pendidikan sebagai berikut menurut Zakiah Daradjat sebagaimana dikutip oleh Abdul Madjid dan Dian Andayani Pendidikan Agama Islam adalah "suatu usaha 
yang sadar untuk membina dan mengasuh peserta didik agar senantiasa dapat memahami ajaran Islam secara menyeluruh, lalu menghayati tujuan, yang pada akhirnya dapat mengamalkan serta menjadikan Islam sebagai pandangan hidup". (Abdul Madjid dan Dian Andayani, 2006: 130)

Berdasarkan Peraturan Menteri No. 22 tahun 2006 tentang Standar Isi menyebutkan bahwa Pendidikan Agama Islam diharapkan menghasilkan manusia yang selalu berupaya menyempurnakan iman, takwa, dan akhlak, serta aktif membangun peradaban dan keharmonisan kehidupan, khususnya dalam memajukan peradaban bangsa yang bermartabat. Manusia seperti itu diharapkan tangguh dalam menghadapi tantangan, hambatan, dan perubahan yang muncul dalam pergaulan masyarakat baik dalam lingkup lokal, nasional, regional maupun global.

Di dalam Kurikulum PAI 2004 sebagaimana dikutip oleh Ramayulis disebutkan bahwa Pendidikan Agama Islam adalah: upaya sadar dan terencana dalam menyiapkan peserta didik untuk mengenal, memahami, menghayati, mengimani, bertakwa, berakhlak mulia, mengamalkan ajaran agama Islam dari sumber utamanya kitab suci Al-Qur'an dan Hadits melalui kegiatan bimbingan pengajaran, latihan, serta penggunaan pengalaman. (Ramayulis, 2005: 21)Sedangkan menurut Tayar Yusuf mengartikan PAI adalah "usaha sadar generasi tua untuk mengalihkan pengalaman, pengetahuan, kecakapan, dan ketrampilan kepada generasi muda agar kelak menjadi manusia bertakwa kepada Allah SWT". (Ramayulis, 2005: 131)

\section{Metode Penelitian}

Penelitian ini termasuk jenis penelitian kajian literatur dengan mencari referensi teori yang relevan dengan kasus atau permasalahan yang ditemukan. Menurut (Creswell, John. W, 2014; 40) menyatakan bahwa Kajian literatur adalah ringkasan tertulis mengenai artikel dari jurnal, buku, dan dokumen lain yang mendeskripsikan teori serta informasi baik masa lalu maupun saat ini mengorganisasikan pustaka ke dalam topik dan dokumen yang dibutuhkan. Jenis data yang digunakan penulis dalam penelitian ini adalah data yang diperoleh dari studi literatur. Studi literatur adalah cara yang dipakai untuk menghimpun data-data atau sumber-sumber yang berhubungan dengan topik yang diangkat dalam suatu penelitian. 


\section{Pembahasan}

\section{Konsep Pembelajaran Pendidikan Agama Islam}

Pendidikan Agama Islam diharapkan menghasilkan manusia yang selalu berupaya menyempurnakan iman, takwa, dan akhlak, serta aktif membangun peradaban dan keharmonisan kehidupan, khususnya dalam memajukan peradaban bangsa yang bermartabat. Manusia seperti itu diharapkan tangguh dalam menghadapi tantangan, hambatan, dan perubahan yang muncul dalam pergaulan masyarakat baik dalam lingkup lokal, nasional, regional maupun global.

Pendidikan Agama Islam diberikan dengan mengikuti tuntunan bahwa agama diajarkan kepada manusia dengan visi untuk mewujudkan manusia yang bertakwa kepada Allah SWT dan berakhlak mulia, serta bertujuan untuk menghasilkan manusia yang jujur, adil, berbudi pekerti, etis, saling menghargai, disiplin, harmonis dan produktif, baik personal maupun sosial. Tuntutan visi ini mendorong dikembangkannya standar kompetesi sesuai dengan jenjang persekolahan yang secara nasional ditandai dengan ciri-ciri: pertama, Lebih menitik beratkan pencapaian kompetensi secata utuh selain penguasaan materi. Kedua, Mengakomodasikan keragaman kebutuhan dan sumber daya pendidikan yang tersedia. Ketiga, Memberikan kebebasan yang lebih luas kepada pendidik di lapangan untuk mengembangkan strategi dan program pembelajaran sesuai dengan kebutuhan dan ketersediaan sumber daya pendidikan. (Ahmad Tafsir, 32)

Tujuan Pendidikan Agama Islam untuk menumbuhkan dan meningkatkan keimanan melalui pemberian dan pemupukan pengetahuan, penghayatan, pengamalan, serta pengalaman peserta didik tentang agama Islam sehingga menjadi manusia muslim yang terus berkembang dalam hal keimanan, ketakwaannya kepada Allah SWT. serta berakhlak mulia dalam kehidupan pribadi, bermasyarakat, berbangsa dan bernegara, serta untuk dapat melanjutkan pada jenjang pendidikan yang lebih tinggi.

Fungsi Pendidikan Agama Islam berfungsi untuk: (1) Penanaman nilai ajaran Islam sebagai pedoman mencapai kebahagiaan hidup di dunia dan akhirat; (2) Pengembangan keimanan dan ketakwaan kepada Allah SWT. Serta akhlak mulia peserta didik seoptimal mungkin, yang telah ditanamkan lebih dahulu dalam lingkungan keluarga; (3) Penyesuaian mental peserta 
didik terhadap lingkungan fisik dan sosial melalui Pendidikan Agama Islam; (4) Perbaikan kesalahan-kesalahan, kelemahankelemahan peserta didik dalam keyakinan, pengamalan ajaran agama Islam dalam kehidupan sehari-hari; (5) Pencegahan peserta didik dari hal-hal negatif budaya asing yang akan dihadapinya seharihari; (6) Pengajaran tentang ilmu pengetahuan keagamaan secara umum (alam nyata dan non nyata/ghaib), sistem dan fungsionalnya; dan (7) Penyaluran siswa untuk mendalami pendidikan agama ke lembaga pendidikan yang lebih tinggi. (Peraturan Menteri Pendidikan Nasional Nomor 20 Tahun 2007, Tentang Standar Penilaian Pendidikan, 2007: 39)

\section{Dasar, Tujuan dan Fungsi Pendidikan Agama Islam}

Menurut Hasan Langgulung, ada lima sumber nilai yang diakui dalam Islam, yaitu Al-Qur'an dan sunnah Nabi sebagai sumber pokok, kemudian Qiyas, kemaslahatan umum yang tidak bertentangan dengan Nash, Ijma' ulama dan ahli pikir islami yang sesuai dengan sumber dasar Islam. Al-Qur'an dan sunnah Nabi merupakan sumber nilai islam yang utama. Sebagai sumber asal, Al-Qur'an memiliki prinsip-prinsip yang masih bersifat global (ijmali), sehingga dalam proses pelaksanaan pendidikan terbuka adanya ijtihad dengan tetap berpegang pada nilai-nilai dan prinsipprinsip dasar Al- Qur'an dan sunnnah Nabi. Dengan demikian dapat dikatakan bahwa sumber nilai yang menjadi dasar pendidikan Islam adalah Al-Qur'an dan sunnah Nabi yang dapat dikembangkan dengan Ijtihad, Al-Maslahah Al-Mursalah, Istihsan, dan Qiyas.

Muhaimin dan Mujib membagi dasar pendidikan Islam menjadi dua bagian, yaitu dasar ideal dan dasar operasional. Dasar ideal, yang dikutip dari Ismail Ali, ada enam macam yaitu AlQur'an, sunnah Nabi, Qawl al-Shahabah, kemaslahatan umat, nilainilai, dan adat kebiasaan, masyarakat serta hasil pemikiran para pemikir Islam. Sedangkan dasar operasional pendidikan Islam terbentuk sebagai aktualisasi dari dasar ideal. Mengutip pendapat Hasan Langgulung, Muhaimin dan Abdul Mujib menguraikan bahwa dasar operasional pendidikan terbagi menjadi empat bagian yang paling dibutuhkan. Pertama dasar historis, dasar ini memberi kesiapan kepada peserta didik dengan hasil-hasil pengalaman masa lalu, Undang-Undang, peraturan-peraturan, batas-batas, dan sekaligus kekurangan-kekurangannya. Kedua, dasar sosial, memilih 
dan mengembangkannnya. Ketiga, dasar psikologis, yaitu dasar yang memberi informasi tentang watak peserta didik, para guru, cara-cara terbaik dalam praktik, pencapaian dan penilaian serta pengukuran. Keempat, dasar filosofis, yaitu dasar yang memberi kemampun memilih yang terbaik, memberi arah suatu sistem, mengontrol dan memberi arah kepada semua dasar-dasar operasional lainnya.

Al-Qur'an dijadikan sebagai acuan pokok dalam melaksanakan pendidikan Islam adalah karena Al-Qur'an merupakan sumber nilai yang bisa dicontoh sebagai penjelas AlQur'an. Oleh karena itu nilai- nilai yang ditanamkan melalui proses pendidikan haruslah diambil dan bersumber dari nilai-nilai yang terkandung dalam Al-Qur'an dan Hadits Nabi. Seperti terdapat dalam surat Ali Imran ayat 110 yang berbunyi:

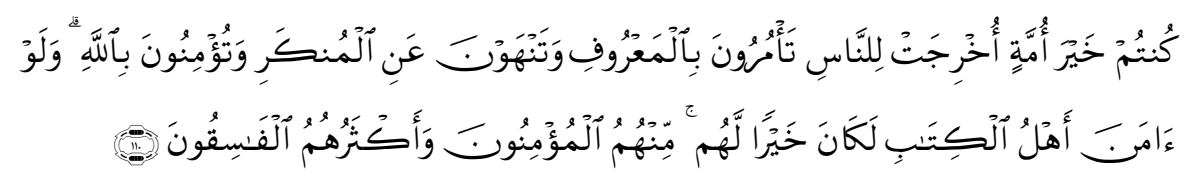

Terjemahannya: Kamu adalah umat yang terbaik yang dilahirkan untuk manusia, menyuruh kepada yang ma'ruf, dan mencegah dari yang munkar, dan beriman kepada Allah. Sekiranya ahli kitab beriman, tentulah itu lebih baik bagi mereka, di antara mereka ada yang beriman, dan kebanyakan mereka adalah orang-orang yang fasik.

Ayat di atas dapat dipahami bahwa manusia adalah diciptakan oleh Tuhan sebagai makhluk terbaik, yang diberi tugas untuk memerintah orang lain agar berbuat: Pertama, amar ma'ruf, yang dalam bahasa Kuntowijoyo bermakna "humanisasi dan emansipasi," maksudnya memanusiakan manusia dan mendudukkan manusia pada posisi sederajat, tak ada perbedaan secara nurani. Kedua, mencegah perbuatan munkar atau leberasi, yaitu membebaskan manusia lain dari penindasan, perlakuan sewenangwenang dan atau bebas dari perbuatan yang merusak nilai kemanusiaannya. Ketiga, disamping kedua hal tersebut di atas, tujuan akhir dari tugas manusia dalam membebaskan manusia lain adalah dilandasi karena tuntutan iman ke arah transendensi, yaitu penyucian 
diri yang ditunjukan melalui kerja kemanusiaan yang ditunjukkan semata-mata hanya karena Allah SWT. Inilah dalam Islam dikenal sebagai manusia yang beruntung atau optimal (muflihun)". (Kuntowijaya, "Manusia", [Online], Available: http://www. manusia.html [2013 Januari, 31]html 1)

Secara partikularistik, di dalam Al-Qur'an terdapat bagianbagian penting, atau ayat-ayat tertentu, atau tema-tema pokok dalam Hadist, yang secara langsung membicarakan tentang proses pendidikan Islam yang didalamnya mengandung unsur materi, tujuan metode, dan evaluasi pendidikan Islam. Seperti dijelaskan dalam QS. Al-Nahl ayat 125:

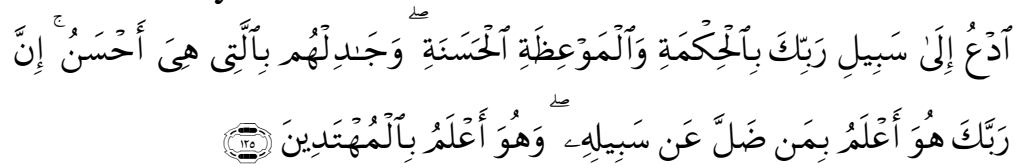

Terjemahannya: Serulah (manusia) kepada jalan Tuhan-mu dengan hikmah dan pelajaran yang baik dan bantahlah mereka dengan cara yang baik. Sesungguhnya Tuhanmu dialah yang lebih mengetahui tentang siapa yang tersesat dari jalan-Nya dan dialah yang lebih mengetahui orang-orang yang mendapat petunjuk. Hikmah, ialah Perkataan yang tegas dan benar yang dapat membedakan antara yang hak dengan yang bathil.

Peserta didik yang dengan serius, tekun, dan memperhatikan materi yang disampaikan oleh pendidik dengan menggunakan berbagai cara/metode/strategi pembelajaran, kemungkinan besar peserta didik akan berhasil atau beruntung dengan memeroleh hasil nilai, indeks prestasi yang memuaskan, namun sebaliknya peserta didik tidak memedulikan atau kurang memerhatikan apa yang disampaikan oleh pendidik, kemungkinan besar akan mendapatkan nilai hasil yang jelek. Allah SWT dalam ayat tersebut secara tegas mengatakan mengetahui siapasiapa hambanya yang sesat dan beruntung setelah disampaikan materi ajaran islam oleh utusan-Nya Muhammad SAW, sebagai pendidik atau penyampai atau pengajak dalam proses pendidikan islam. Dan masih banyak lagi ayat-ayat dalam Al-Qur'an yang secara langsung menjelaskan proses kegiatan pendidikan Islam. Dan masih banyak lagi ayat-ayat dalam Al-Qur'an yang secara langsung menjelaskan proses kegiatan pendidikan, seperti QS. Al-Alaq, QS. 
Al-Baqarah: 31,133, QS. Luqman: 12-19, QS. Al-Dzariyat: 56, dan lain sebagainya. Dalam Hadist Nabi juga disebutkan sebagaimana artinya yang berbunyi:

Artinya: "Abdullah Bin Amra Bin Al-Ashro berkata: bersabda Nabi SAW: sampaikanlah dari ajaranku walaupun hanya satu ayat dan ceritakanlah Bani Israil dengan terbatas dan barang siapa yang berdusta atas namaku dengan sengaja hendaknya menentukan tempat di api neraka" (HR. Bukhari Muslim)". (Fatah Yasin, 2008: 46)

Kata "Islam" dalam "pendidikan Islam" menunjukkan warna pendidikan tertentu, yaitu pendidikan yang berwarna islam, pendidikan yang Islami, yaitu pendidikan yang berdasarkan Islam. Jelas, pertanyaan yang hendak dijawab ialah: "apa pendidikan itu menurut Islam?" untuk menjawab pertanyaan ini lebih dahulu dibahas definisi pendidikan itu menurut Islam. Pembahasan tentang apa pendidikan itu menurut Islam terutama didasarkan atas keterangan Al-Qur'an dan Hadist, kadang-kadang diambil juga pendapat para pakar pendidikan Islam.

Dalam bukunya Ahmad Tafsir mengartikan pendidikan ialah "pengembangan pribadi dalam semua aspeknya, dengan penjelasan bahwa yang dimaksud pengembangan pribadi ialah yang mencakup pendidikan oleh diri sendiri, pendidikan oleh lingkungan, dan pendidikan oleh orang lain (guru). Seluruh aspek mencakup jasmani, akal, dan hati”. (Fatah Yasin, 2008: 84) Menurut Naquib Al-Attas istilah ta'dib adalah istilah yang paling tepat digunakan untuk menggambarkan pengertian pendidikan, sementara istilah tarbiyyah terlalu luas karena pendidikan dalam istilah ini mencakupi juga pendidikan untuk hewan. Selanjutnya ia menjelaskan bahwa istilah ta'dib merupakan masdar kata kerja addaba yang berarti pendidikan. Dari kata addaba ini diturunkan juga kata adabun. Menurut Al-Attas, adabun berarti "pengenalan dan pengakuan tentang hakikat bahwa pengetahuan dan wujud bersifat teratur secara hierarkis sesuai dengan berbagai tingkat dan derajat tingkatan mereka dan tentang tempat seseorang yang tepat dalam hubungannya dengan hakikat itu serta dengan kapasitas dan potensi jasmaniah, intelektual maupun rohaniah seseorang berdasarkan pengertian adab seperti itu, Al-Attas mendefinisikan pendidikan (menurut islam) sebagai pengenalan dan pengkuan yang secara berangsur-angsur ditanamkan ke dalam manusia, tentang tempat-tempat yang tepat 
bagi segala sesuatu di dalam tatanan wujud sehingga ini membimbing ke arah pengenalan dan pengakuan tempat Tuhan yang tepat di dalam tatanan wujud tersebut. (Naquib Al-Attas, "Pendidikan menurut Islam", [Online], Available: http://www. pendidikan-menurut-islam.html [2013 Januari, 31], hlm. 5)

\section{Pengertian hasil belajar}

Hasil belajar adalah tingkah laku yang ditunjukkan siswa setelah melakukan kegiatan belajar. Hal itu sesuai dengan pernyataan Marfungtun bahwa hasil belajar adalah "kebetulan pada tingkah laku". (Marfungatun, "Pengaruh Kegiatan Pembelajaran Sore Hari Terhadap Prestasi Belajar Siswa Pada Mata Peleajaran Fiqih di MA Ittihaadul Ulum Lubuklinggau", Skripsi Sarjana S.1 pada STAIS Bumi Silampari Lubuklinggau, 2011:19) Pola tingkah laku tersebut terlihat pada pembuatan reaksi dan sikap siswa secara fisik maupun mental.

Kurikulum Pendidikan Islam. Dalam pembahasan ini tidak dibahas kurikulum secara mendalam, sudah banyak buku dalam bahasa Indonesia yang membahas persoalan itu. Buku-buku yang membicarakan kurikulum dalam bahasa Indonesia itu semuanya dapat digunakan oleh para pendidikan islam, para pelajar, para pengelola dan guru pada lembaga pendidikan Islam, sekurangkurangnya sebagai bahan bandingan. Kata "kurikulum" mulai dikenal sebagai istilah dalam dunia pendidikan sejak kurang-lebih satu abad yang lalu. Istilah kurikulum untuk pertama kalinya dalam kamus Webster tahun 1856. Pada tahun itu kurikulum digunakan dalam bidang olah raga, yakni suatu alat yang membawa orang dari start sampai ke finish. Barulah pada tahun 1955 istilah kurikulum dipakai dalam bidang pendidikan dengan arti sejumlah mata pelajaran disuatu perguruan. Dalam kamus tersebut kurikulum diartikan dua macam, yaitu: pertama, Sejumlah mata pelajaran yang harus ditempuh atau pelajaran siswa di sekolah atau perguruan tinggi untuk memperolah ijazah tertentu. Kedua, Sejumlah mata pelajaran yang ditawarkan oleh suatu lembaga pendidikan atau jurusan". (Marfungatun, "Pengaruh Kegiatan Pembelajaran Sore Hari Terhadap Prestasi Belajar Siswa Pada Mata Peleajaran Fiqih di MA Ittihaadul Ulum Lubuklinggau", Skripsi Sarjana S.1 pada STAIS Bumi Silampari Lubuklinggau, 2011:53) 
Menurut pandangan modern, kurikulum lebih dari sekedar rencana pelajaran atau bidang studi. Kurikulum dalam pandangan modern ialah semua yang secara nyata terjadi dalam proses pendidikan di sekolah. Pandangan ini bertolak dari sesuatu yang aktual, yang nyata, yaitu yang aktual terjadi di sekolah dalam proses belajar. Di dalam pendidikan, kegiatan yang dilakukan siswa dapat memberikan pengalaman pelajaran, seperti berkebun, olah raga, pramuka, dan pergaulan, selain mempelajari bidang studi. Semuanya itu merupakan pengalaman belajar yang bermanfaat. Pandangan modern berpendapat bahwa semua pengalaman pelajaran itulah kurikulum.Tujuan itu mula-mula bersifat umum. Dalam operasinya tujuan tersebut harus dibagi menjadi bagian-bagian yang "kecil".

Komponen proses belajar-mengajar mempertimbangkan kegiatan anak dan guru dalam proses belajar-mengajar. Dalam proses belajar itu anak sebaiknya tidak dibiarkan sendirian. Dibiarkan memang mungkin, tetapi hasil belajar oleh anak sendirian biasanya kurang maksimal. Karena itulah para ahli menyebut para proses belajar itu dengan proses belajar-mengajar karena memang proses itu merupakan gabungan kegiatan anak belajar dan guru mengajar yang tidak terpisahkan. Mutu proses akan banyak ditentukan oleh kemampuan guru (pendidik)-nya. Proses belajarmengajar adalah kegiatan dalam mencapai tujuan. Proses ini sering disebut sebagai metode mencapai tujuan. Mutu proses itu banyak sekali bergantung pada kemampuan guru dalam menguasai dan mengaplikasikan teori-teori keilmuan, yaitu teori psikologi, khususnya psikologi pendidikan, metodologi mengajar, metode belajar, penggunaan alat pengajaran, dan sebagainya.

Adapun komponen keempat, yaitu evaluasi, itu adalah kegiatan kurikuler berupa penilaian untuk mengetahui berapa persen tujuan tadi dapat dicapi. Bagaimana cara menilai itu? Ada sains khusus yang membicarakan ini, namanya "teknik evaluasi", yang kelihatannya kurang banyak ditulis oleh para ahli kalangan Muslim. Hasil penilaian itu biasanya berupa angka, yang dinyatakan sebagai angka yang dicapai siswa.

\section{Materi Pendidikan Agama Islam}

Materi Pendidikan Agama Islam adalah bahan-bahan pelajaran yang Standar kompetensi mata pelajaran Pendidikan 
Agama Islam (PAI) berisi sekumpulan kemampuan minimal yang harus dikuasai siswa selama menempuh PAI di SD. Kemampuan ini berorientasi pada perilaku afektif dan psikomotorik dengan dukungan pengetahuan kognitif dalam rangka memperkuat keimanan dan ketaqwaan kepada Allah SWT. Kemampuankemampuan yang tercantum dalam komponen kemampuan dasar ini merupakan penjabaran dari kemampuan dasar umum yang harus dicapai di SD yaitu:

a) Mampu membaca $\mathrm{Al}$ Qur'an surat-surat pilihan sesuai dengan tajwidnya, mengartikan, dan menyalinnya, serta mampu membaca, mengartikan, dan menyalin hadits-hadits pilihan.

b) Beriman kepada Allah SWT. dan lima rukun iman yang lain dengan mengetahui fungsinya serta terefleksi dalam sikap, perilaku, dan akhlak peserta didik dalam dimensi vertikal maupun horizontal.

c) Mampu beribadah dengan baik dan benar sesuai dengan tuntunan syari'at Islam baik ibadah wajib dan ibadah sunnah maupun muamalah.

d) Mampu berakhlak mulia dengan meneladani sifat, sikap, dan kepribadian Rasulullah serta Khulafaur Rasyidin.

e) Mampu mengambil manfaat dari sejarah peradaban Islam. Seperti tergambar dalam kemampuan dasar umum di atas, kemampuan dasar tiap kelas yang tercantum dalam Standar Nasional juga dikelompokkan ke dalam lima unsur pokok mata pelajaran Pendidikan Agama Islam di SMP, yaitu: Al Quran/Hadits, Keimanan, Akhlak, Fiqih/Ibadah, dan Tarikh. Berdasarkan pengelompokan per unsur, kemampuan dasar mata pelajaran Pendidikan Agama Islam di SD adalah sebagai berikut:

Al Quran/Hadits:

1) Membaca, mengartikan, dan menyalin surat-surat pilihan.

2) Membaca, mengartikan, dan menyalin hadits-hadits pilihan.

Menerapkan hukum bacaan Alif Lam Syamsiyah dan Alif lam Qomariah, Nun mati/tanwin dan mim mati.

3) Menerapkan bacaan qalqalah, tafkhim dan tarqiq, huru f lam dan ra', serta mad.

4) Menerapkan hukum bacaan waqof dan idgham.

5) Mengamalkan isi kandungan Al Quran dan Hadits dalam 
kehidupan sehari-hari. (SD Negeri 2 Air Lesing, Kurikulum SD Negeri 2 Air Lesing Kec. Tuah Negeri Tahun Pelajaran 2014/2015, (Lesing: SD Negeri 2 Air Lesing, 2015: 8)

Keimanan

(1) Beriman kepada Allah SWT, dan memahami sifat-sifat-Nya.

(2) Beriman kepada Malaikat-malaikat Allah SWT, dan memahami tugas-tugasnya.

(3) Beriman kepada Kitab-kitab Allah SWT, dan memahami arti beriman kepadanya.

(4) Beriman kepada Rasul-rasul Allah SWT, dan memahami arti beriman kepadanya.

(5) Beriman kepada hari akhir dan memahami arti beriman kepadanya. (SD Negeri 2 Air Lesing, Kurikulum SD Negeri 2 Air Lesing Kec. Tuah Negeri Tahun Pelajaran 2014/2015, (Lesing: SD Negeri 2 Air Lesing, 2015), hlm. 6)
Akhlak
(1) Beperilaku dengan sifat-sifat terpuji.
(2) Menghindari sifat-sifat tercela.
(3) Bertata krama. ${ }^{1}$

Fiqih/Ibadah

(1) Melakukan thaharah/bersuci.

(2) Melakukan shalat wajib.

(3) Melakukan macam-macam sujud.

(4) Melakukan shalat Jum'at.

(5) Melakukan shalat jama' dan qashar.

(6) Melakukan macam-macam shalat sunnah.

(7) Melakukan puasa.

(8) Melakukan zakat.

(9) Memahami hukum Islam tentang makanan, minuman, dan binatang.

(10) Memahami ketentuan aqiqah dan qurban.

(11) Memahami ibadah haji dan umrah.

(12) Melakukan shalat janazah.

(13) Memahami tata cara pernikahan. 
Tarikh

(1) Memahami keadaan masyarakat Makkah sebelum dan sesudah Islam datang.

2) Memahami keadaan masyarakat Makkah periode Rasulullah SAW.

3) Memahami keadaan masyarakat Madinah sebelum dan sesudah Islam datang.

4) Memahami perkembangan Islam pada masa Khulafaur Rasyidin.

Pendidik diharapkan dapat mengembangkan metode pembelajaran sesuai dengan standar kompetensi dan kompetensi dasar. Pencapaian seluruh kompetensi dasar perilaku terpuji dapat dilakukan tidak beraturan. Peran semua unsur sekolah, orang tua siswa dan masyarakat sangat penting dalam mendukung keberhasilan pencapaian tujuan Pendidikan Agama Islam.

\section{Perilaku Belajar}

Perilaku adalah "suatu perbuatan atau aktivitas atau sembarang respons baik itu reaksi, tanggapan, jawaban, atau itu balasan yang dilakukan oleh suatu organisme. Secara khusus pengertian perilaku adalah bagian dari satu kesatuan pola reaksi". (Walgito Andi, 2003: 53) Perilaku menurut M. Syah adalah "suatu aktivitas yang mengalami perubahan dalam diri individu. Perubahan itu didapat dalam segi kognitif, afektif, dan dalam segi psikomotorik". (M. Syah, 2005: 68) Dari pengertian di atas dapat di simpulkan bahwa perilaku adalah tanggapan atau reaksi individu terhadap rangsangan atau lingkungan. Dari pandangan biologis perilaku merupakan suatu kegiatan atau aktifitas organisme yang bersangkutan. Walgito, memberikan definisi tentang belajar sebagai berikut: Belajar dapat diartikan sebagai "perubahan yang relatif menetap pada perilaku yang terjadi sebagai akibat dari latihan atau pengalaman". (Walgito, B, 166) Hal yang muncul dalam definisi ini adalah bahwa perubahan perilaku atau performance itu relatif permanen. Di samping itu juga dikemukakan bahwa perubahan perilaku itu sebagai akibat belajar karena latihan (practice) atau karena pengalaman (experience). Pada pengertian latihan dibutuhkan usaha dari individu yang bersangkutan, sedangkan pada pengertian pengalaman usaha tersebut tidak tentu 
diperlukan. Ini mengandung arti bahwa dengan pengalaman seseorang atau individu dapat berubah perilakunya, di samping perubahan itu dapat disebabkan oleh karena latihan.

Skinner memberikan definisi belajar sebagai sebuah proses adaptasi perilaku yang progresif. Belajar sendiri merupakan suatu proses dari tidak tahu menjadi tahu, dari tidak mengerti menjadi mengerti dan sebagainya, untuk memperoleh perubahan tingkah laku yang lebih baik secara keseluruhan akibat interaksinya dengan lingkungannya. Dari definisi tersebut dapat dikemukakan bahwa belajar itu merupakan suatu proses adaptasi perilaku yang bersifat progresif. Ini berarti bahwa sebagai akibat dari belajar adanya sifat progresivitas, adanya tendensi ke arah yang lebih sempurna atau lebih baik dari keadaan sebelumnya. Menurut Syah belajar adalah "tahapan perubahan seluruh tingkah laku individu yang relatif menetap sebagi hasil pengalaman dan interaksi dengan lingkungan yang melibatkan proses kognitif". (Walgito Andi, 2003: 92) Sehubungan dengan pengertian itu perlu diutarakan sekali lagi bahwa perubahan tingkah laku yang timbul akibat proses kematangan, keadaan gila, mabuk, lelah, dan jenuh tidak dapat dipandang sebagai proses belajar. Meskipun secara teoritis belajar dapat diartikan sebagai perubahan tingkah laku, namun tidak semua perubahan tingkah laku organism dapat dianggap belajar. Perubahan yang timbul karena proses belajar sudah tentu memiliki ciri-ciri perwujudan yang khas. Setiap perilaku belajar selalu ditandai oleh ciri-ciri perubahan yang spesifik.

Karakteristik perilaku belajar ini dalam beberapa pustaka rujukan, antara lain psikologi pendidikan oleh Suryabrata, disebut juga sebagai prinsip-prinsip belajar. Diantara ciri-ciri perubahan khas yang menjadi karakteristik perilaku belajar yang terpenting adalah: "1. Perubahan itu intensional, 2. Perubahan itu positif dan aktif dan 3. Perubahan itu efektif dan fungsional". (Djaali, 2012: 32) Belajar merupakan kegiatan mental yang tidak dapat disaksikan dari luar. Apa yang sedang terjadi dalam diri seseorang yang sedang belajar, tidak dapat diketahui secara langsung hanya dengan mengamati orang itu. Bahkan, hasil belajar orang itu dapat langsung kelihatan, tanpa orang itu melakukan sesuatu yang menampakkan kemampuan yang telah diperoleh melalui belajar.

Dari uraian di atas, dapat disimpulkan bahwa perilaku belajar adalah suatu aktivitas mental / psikis, yang berlangsung dalam interaksi aktif dengan lingkungan, yang menghasilkan perubahan- 
perubahan dalam pengetahuan pemahaman, ketrampilan dan nilai sikap.

\section{Perwujudan Perilaku Belajar}

Menurut M. Syah, dalam memahami arti belajar dan inti dasar perubahan sikap karena belajar, para ahli sependapat bahwa perilaku belajar diwujudkan dalam sembilan bentuk, yaitu: kebiasaan, ketrampilan, pengamatan, berfikir asosiatif dan daya ingat, berfikir rasional dan kritis, sikap, apresiasi, dan tingkah laku afektif. Adapun penjabaran dari ke sembilan bentuk perilaku belajar adalah:

a. Kebiasaan, setiap siswa yang telah mengalami proses belajar, kebiasaannya akan berubah.

b. Ketrampilan, adalah kegiatan yang berhubungan dengan urat-urat syaraf dan otot-otot (neuromuscular) yang lazimnya tampak dalam kegiatan jasmaniah seperti menulis, mengetik, olah raga, dan sebagainya.

c. Pengamatan, adalah proses menerima, menafsirkan, dan member arti rangsangan yang masuk melalui indra-indra seperti mata dan telinga.

d. Berpikir asosiatif dan daya ingat, secara sederhana dapat diartikan berpikir dengan cara mengasosiasikan sesuatu dengan lainnya. Berpikir asosiatif itu merupakan proses pembentukan hubungan antara rangsangan dengan respon.

e. Berpikir rasional dan kritis, adalah perwujudan perilaku belajar terutama yang bertalian dengan pemecahan masalah.

f. Sikap, dalam arti yang sempit diartikan sebagai pandangan atau kecenderungan mental.

g. Inhibisi, secara ringkas diartikan sebagai upaya pengurangan atau pencegahan timbulnya suatu respon tertentu karena adanya proses respon lain yang sedang berlangsung.

h. Apresiasi, pada dasarnya berarti suatu pertimbangan (judgment) mengenai arti penting atau nilai sesuatu.

i. Tingkah laku afektif, adalah tingkah laku yang menyangkut keanekaragaman perasaan seperti takut, marah, sedih, gembira, kecewa, senang, benci, waswas, dan sebagainya. Tingkah laku seperti ini tidak terlepas dari pengaruh pengalaman belajar. Oleh karenanya, dia juga dapat dianggap sebagai perwujudan perilaku belajar. (M. Syah, 118) 
Dari uraian di atas, dapat disimpulkan perilaku belajar terwujud dalam bentuk kebiasaan, ketrampilan, pengamatan, berpikir asosiatif dan daya ingat, berpikir rasional dan kritis, sikap, inhibisi, apresiasi dan tingkah laku afektif. Dari ke sembilan bentuk perilaku belajar, penulis hanya mengambil lima bentuk sebagai aspek dalam pembuatan skala sikap, yaitu pengamatan, berpikir asosiatif, berpikir rasional dan kritis, inhibisi, dan apresiasi. Alasannya, karena didalam kelima aspek tersebut sudah dapat mewakili secara keseluruhan. Peneliti hanya mengambil satu teori dari satu tokoh saja karena tokoh tersebut dalam bukunya sudah merangkum pendapat-pendapat tokoh yang lain.

\section{Faktor-faktor yang Mempengaruhi Perilaku Belajar}

Menurut M. Syah, secara global faktor-faktor yang mempengaruhi perilaku belajar siswa dapat dibedakan kedalam tiga faktor diantaranya: a) Faktor Internal Siswa, b) Faktor Eksternal c) Faktor pendekatan belajar". (M. Syah, 132)

Faktor Internal Siswa

Fisiologis

Tonus Jasmani yang menandai tingkat kebugaran organ - organ tubuh dan sendi-sendinya, dapat mempengaruhi semangat dan intesitas siswa dalam mengikuti pelajaran. Kondisi organ tubuh yang lemah, apalagi jika disertai pusing-pusing kepala misalnya, dapat menurunkan kualitas ranah cipta (kognitif) sehingga materi yang dipelajarinya pun kurang atau tidak berbekas.

Psikologis

Inteligensi

Inteligensi pada umumnya dapat diartikan sebagai kemampuan psiko - fisik untuk mereaksi rangsangan atau menyesuaikan diri dengan lingkungan dengan cara yang tepat.

Sikap

Sikap adalah gejala internal yang berdimensi afektif berupa kecenderungan untuk mereaksi atau merespon dengan cara yang relatif tetap terhadap obyek orang, barang, dan sebagainya, baik secara positif maupun negatif.

Bakat

Secara umum bakat adalah kemampuan potensialyang dimiliki seseorang untuk mencapai keberhasilan pada masa yang akan datang. Dengan demikian, sebetulnya setiap orang pasti memiliki bakat 
dalam arti berpotensi untuk mencapai prestasi sampai ketingkat tertentu sesuai dengan kepasitas masing - masing. Jadi secara global itu bakat itu mirip dengan inteligensi.

\section{Minat}

Minat berarti kecenderungan dan kegairahan yang tinggi atau keinginan yang besar terhadap sesuatu.

Motivasi

Motivasi adalah keadaan internal organisme - baik manusia maupun hewan- yang mendorongnya berbuat sesuatu. Dalam pengertian ini, motivasi berarti pemasok daya (energizer) untuk bertingkah laku secara terarah.

\section{Faktor Eksternal}

\section{Lingkungan sosial}

Lingkungan sosial sekolah seperti guru dan teman sekelas, yang dapat mempengaruhi semangat belajar seorang siswa sehingga menjadi daya dorong yang positif bagi kegiatan belajar siswa. Lingkungan sosial yang lebih banyak mempengaruhi kegitan belajar ialah orang tua dan siswa itu sendiri, karena sifat-sifat dan pengelolaan keluarga semunya dapat memberi dampak baik dan buruk terhadap kegiatan belajar dan hasil yang dicapai nantinya.

\section{Lingkungan Non-sosial}

Yang termasuk disini adalah: gedung sekolah dan letaknya, rumah tempat tinggal keluarga dan letaknya, alat-alat belajar, keadaan cuaca dan waktu belajar yang digunakan siswa. Faktor-faktor ini dipandang turut menentukan tingkat keberhasilan belajar siswa.

\section{Faktor pendekatan belajar}

Pendekatan belajar, seperti yang telah diuraikan secara panjang lebar pada sub bab sebelumnya, dapat dipahami sebagai segala cara atau strategi yang digunakan siswa dalam menunjang efektivitas dan efisiensi proses pembelajaran materi tertentu. Berdasarkan uraian diatas, dapat disimpulkan bahwa factor-faktor yang mempengaruhi perilaku belajar adalah faktor internal yang terdiri dari fisiologis dan psikologis, faktor eksternal yang terdiri dari lingkungan sosial dan non sosial, dan yang terakhir faktor pendekatan belajar siswa. Peneliti hanya mengambil satu teori dari satu tokoh saja yaitu Syah, karena tokoh tersebut dalam bukunya sudah merangkum pendapat-pendapat tokoh yang lain. Faktor-faktor di atas 
sudah dapat mewakili dukungan sosial dan kemandirian. Dalam penelitian ini, peneliti mengangkat faktor internal dan faktor eksternal sebagai faktor yang mempengaruhi perilaku belajar dengan alasan kedua faktor tersebut ada dalam dukungan sosial dan kemandirian.

Dengan demikian perubahan perilaku peserta didik adalah perwujudan yang ditimbulkan oleh suatu kebiasaan yang dilakukan oleh seorang terus menerus, baik akibat positif maupun negatif. Faktor inter dan faktor ekstern akan sangat menentukan dalam kelangsungan perubahan perilaku peserta didik.waktu dan proses yang lama, akan menjadi seseorang mengalami perubahan-perubahan karakteristiknya, bahkan aspek keagamaan pun bisa berubah.

\section{Simpulan}

Pandangan tentang masalah pendidikan Islam merupakan suatu untuk membina dan mengasuh peserta didik agar senantiasa dapat memahami ajaran Islam secara menyeluruh, kemudian menghayati tujuan yang pada akhirnya dapat mengamalkan serta menjadikan Islam sebagai pandangan hidup. Dengan tujuan untuk menumbuhkan dan meningkatkan keimanan melalui pemberian dan pemupukan pengetahuan, penghayatan, pengamalan, serta pengalaman peserta didik tentang agama Islam sehingga menjadi manusia muslim yang terus berkembang dalam hal keimanan, ketakwaannya kepada Allah SWT. serta berakhlak mulia.

Prilaku belajar merupakan perubahan sikap belajar peserta didik. Dengan menerima materi pendidikan Agama Islam menimbulkan prilaku yang agamis. Dengan memahami faktor-faktor yang mempengaruhi prilaku belajar, dan pendekatan prilaku belajar yang bertujuan untuk membentuk prilaku yang baik dari belajar, menjadikan akhlak yang baik sehingga tercapailah tujuan pembelajaran membentuk kepribadian muslim. 


\section{DAFTAR PUSTAKA}

B, Walgito. 2003. Pengantar Psikologi Umum, Andi: Yogyakarta.

Djaali,. 2012. Psikologi Pendidikan, Bumi Aksara: Jakarta.

Kuntowijaya, "Manusia", [Online], Available: http://www. manusia.html [2013 Januari, 31].

Madjid, Abdul dan Dian Andayani. 2006. Pendidikan Agama Islam Berbasis Kompetensi, Remaja Rosda Karya: Bandung.

Marfungatun,. 2011. "Pengaruh Kegiatan Pembelajaran Sore Hari Terhadap Prestasi Belajar Siswa Pada Mata Peleajaran Fiqih di MA Ittihaadul Ulum Lubuklinggau", Skripsi Sarjana S.1 pada STAIS Bumi Silampari Lubuklinggau, Lubuklinggau: STAIS Bumi Silampari Lubuklinggau.

Naquib Al-Attas, "Pendidikan menurut Islam", [Online], Available: http://www. pendidikan-menurut-islam.html, 2013 Januari, 31

Peraturan Menteri Pendidikan Nasional Nomor 20 Tahun 2007, Tentang Standar Penilaian Pendidikan, Jakarta: Restindo Mediatama, 2007.

Ramayulis,. 2005. Metodologi Pendidikan Agama Islam, Kalam Mulia: Jakarta.

SD Negeri 2 Air Lesing, Kurikulum SD Negeri 2 Air Lesing Kec. Tuah Negeri Tahun Pelajaran 2014/2015.

Sujari, [Online $], \quad$ Available: http://suhatmanate.blogspot.com/2009/01/pentingnya-pendidikan-agamaislam. tanggal 24 Mei 2013

Syah, M. 2005. Psikologi Pendidikan dengan Pendekatan Baru, PT. Remaja Rosdakarya: Bandung. 
36 Nurlila Kamsi, Prilaku Belajar Dalam Konsep, .....

Tafsir, Ahmad. 2005. Ilmu Pendidikan dalam Perspektif Islam, PT Remaja Rosdakarya: Bandung.

Yasin. Fatah, 2008. Dimensi-Dimensi Pendidikan Islam, UIN Malang Press: Malang. 